\title{
Correction to "Sustainability of an Enhanced Recovery After Surgery initiative for elective colorectal resections in a community hospital"
}

he translated abstract of the article "Sustainability of an Enhanced Recovery After Surgery initiative for elective colorectal resections in a community hospital" by Norman and colleagues, ${ }^{1}$ published in the May-June issue, contained an error. The French conclusion paragraph should have read as follows:

La durée des séjours à l'hôpital a diminué après l'adoption du programme de RAAC, lorsque le coordonnateur du programme était présent. Les méthodes de maintien des lignes directrices après leur adoption seront cruciales au succès de programmes similaires à l'avenir.

We apologize for the error. The article has been corrected at canjsurg.ca. DOI: 10.1503/cjs.2063301

\section{Reference}

1. Norman A, Mahoney K, Ballah E, et al. Sustainability of an Enhanced Recovery After Surgery initiative for elective colorectal resections in a community hospital. Can 7 Surg 2020;63:E292-8. 